\title{
Effects of cromolyn and nedocromil on ion currents in canine tracheal smooth muscle
}

\author{
L.J. Janssen, J. Wattie, P-A. Betti
}

Effects of cromolyn and nedocromil on ion currents in canine tracheal smooth muscle. L.J. Janssen, J. Wattie, P-A. Betti. OERS Journals Ltd 1998.

ABSTRACT: Cromolyn and nedocromil are often used in the treatment of asthma. Recently, these agents have been shown to block $\mathrm{Cl}$ currents and/or $\mathrm{Ca}^{2+}$ currents in a variety of cell preparations. $\mathrm{Ca}^{2+}$ and $\mathrm{Cl}$ currents play central roles in excitation-contraction coupling in airway smooth muscle. This study therefore aimed to investigate the effects of these agents on membrane currents, elevations of $\left[\mathrm{Ca}^{2+}\right]$ and contractions evoked by depolarization and/or acetylcholine in airway smooth muscle.

Patch-clamp, fura-2 fluorimetric and muscle-bath techniques were used to monitor ion currents, $\left[\mathrm{Ca}^{2+}\right]$ and contractions, respectively, in canine tracheal smooth muscle in the presence and absence of the chromones.

Cromolyn and nedocromil eliminated voltage-dependent $\mathrm{Ca}^{2+}$ currents, leading to a reduction in depolarization-evoked $\mathrm{K}^{+}$currents. Both chromones had little or no effect on either acetylcholine-evoked release of internal $\mathrm{Ca}^{2+}$ or the subsequent contraction; however, cromolyn (but not nedocromil) at high concentrations suppressed $\mathrm{Ca}^{2+}$ dependent $\mathrm{Cl}$ - currents triggered by acetylcholine.

In conclusion, cromolyn and nedocromil abolished voltage-dependent $\mathrm{Ca}^{2+}$ currents and cromolyn also suppressed $\mathrm{Ca}^{2+-d e p e n d e n t ~} \mathrm{Cl}$ - currents in airway smooth muscle; neither chromone greatly altered either the release of internally sequestered $\mathrm{Ca}^{2+}$ or the resultant contractions. Further investigation is needed to determine whether the local concentrations obtained by inhaled chromones within the airway wall allow these cellular effects to occur in patients in vivo.

Eur Respir J 1998; 12: 50-56.

Electrophysiological studies of airway smooth muscle (ASM) have identified several ionic currents which are activated during membrane depolarization. In direct response to the change in membrane potential, voltage-dependent $\mathrm{Ca}^{2+}$ currents and at least two different $\mathrm{K}^{+}$currents (delayed rectifier and $\mathrm{Ca}^{2+-d e p e n d e n t)}$ are activated [1-4]. Opening of the $\mathrm{Ca}^{2+}$ channels results in $\mathrm{Ca}^{2+}$ influx, which in turn contributes further to $\mathrm{Ca}^{2+}$-dependent $\mathrm{K}^{+}$channel activity and activates $\mathrm{Ca}^{2+}$-dependent $\mathrm{Cl}$ - currents [5]. All of these currents have unique activation, inactivation and deactivation characteristics and distinct pharmacological sensitivities which allow them to be distinguished and studied in relative isolation using patch-clamp techniques. Various physiological responses are closely linked to changes in activity of these membrane currents. For example, voltage-dependent $\mathrm{Ca}^{2+}$ channels are involved in excitationcontraction coupling by mediating voltage-dependent $\mathrm{Ca}^{2+-}$ influx (electromechanical coupling) as well as refilling of the internal $\mathrm{Ca}^{2+}$ pool $[2-4,6] . \mathrm{K}^{+}$channels mediate membrane hyperpolarization and are therefore important in setting the resting state of the cell and/or inhibiting excitation. As such, many relaxants act by opening these channels while spasmogens act in part by suppressing their activity [7]. $\mathrm{Cl}^{-}$channels contribute to the membrane depolarization in response to spasmogenic stimulation [7-9]. In addition to the conductance changes described above, many spasmogens also activate a nonselective cation current [8, 9], although the signalling mechanisms underlying this response are still unclear.
Asthma Research Group, Smooth Muscle Research Program, Dept of Medicine, McMaster University, Hamilton, Ontario, Canada.

Correspondence: L.J. Janssen, Dept of Medicine, McMaster University, Hamilton, Ontario, Canada L8N 3Z5, Fax: 9055215053

Keywords: $\mathrm{Ca}^{2+-d e p e n d e n t ~} \mathrm{Cl}$ - currents $\mathrm{Ca}^{2+}$-dependent $\mathrm{K}^{+}$currents sarcoplasmic reticulum voltage-dependent $\mathrm{Ca}^{2+}$ currents

Received: November 201997 Accepted after revision April 211998 Supported by grants from the Medical Research Council of Canada and the Ontario Thoracic Society, as well as a Career Award to L.J. Janssen from the Pharmaceutical Manufacturer's Association of Canada and the Medical Research Council of Canada.
Asthma is characterized by airway hyperresponsiveness and bronchoconstriction. Since it is believed that the sequence of events leading to asthma begins with airway inflammation, the widely accepted prophylactic approach to the treatment of asthma is the use of anti-inflammatory agents, of which the most effective are inhaled corticosteroids $[10,11]$. In addition to steroids, other drugs including the chromones nedocromil and cromolyn sodium mediate a variety of effects including suppression of the release of inflammatory mediators and cytokines from mast cells [1012]. However, there is still considerable controversy with respect to the precise mechanism of action of these nonsteroidal anti-inflammatory agents $[10,11]$.

Recently, a number of these nonsteroidal anti-inflammatory agents have been found to exert effects on ion channels. For example, cromolyn sodium and nedocromil block $\mathrm{Cl}^{-}$channels in cultured mast cells $[13,14]$, colonic carcinoma cells [14], airway epithelial cells [15], mouse 3T3 fibroblasts [16] and bovine pulmonary arterial endothelial cells [17]. In rabbit vagal C-fibres, however, nedocromil first activates $\mathrm{Cl}$ - channels, then suppresses them [18]. Cromolyn sodium also blocks the $\mathrm{Ca}^{2+}$ conductance, which mediates refilling of the internal $\mathrm{Ca}^{2+}$ pool of rat peritoneal mast cells [13].

In light of the influence that these commonly used clinical agents may have on $\mathrm{Ca}^{2+}$ homeostasis and ion channels, which play central roles in ASM excitability, this study sought to examine their effects on the activity of canine ASM. 


\section{Materials and methods}

\section{Preparation of tissues and cell dissociation}

Adult mongrel dogs were killed with pentobarbital sodium (100 mg. $\left.\mathrm{kg}^{-1}\right)$. Tracheae were excised, kept in Ringer's solution and dissected to remove overlying connective tissue, vasculature and epithelium. Trachealis muscle was then cut into strips parallel to the muscle fibres ( $\sim 1 \mathrm{~mm}$ wide) and transferred to Ringer's buffer for use in muscle baths (see below) or in enzyme-containing dissociation buffer (0.5-1.0 g wet weight $\cdot \mathrm{mL}^{-1}$; composition given below). Tissues were either used immediately or stored at $4{ }^{\circ} \mathrm{C}$ for use up to $48 \mathrm{~h}$ later; it was previously found that tissues or cells studied immediately exhibit similar functional responses to those used after refrigeration. To liberate single ASM cells, tissues in enzyme-containing solution were incubated at $37^{\circ} \mathrm{C}$ for $60-120 \mathrm{~min}$, then gently triturated.

\section{Patch-clamp electrophysiology}

Single ASM cells were allowed to settle and adhere to the bottom of a recording chamber $(1 \mathrm{~mL}$ bath volume, perfused at $\left.2-3 \mathrm{~mL} \cdot \mathrm{min}^{-1}\right)$ and were studied within $6 \mathrm{~h}$. Membrane currents were recorded using the nystatin perforated patch method to limit "run-down" of currents. Electrode tip resistances ranged from 3-5 $\mathrm{M} \Omega$, with access resistance of 10-20 M . Data were filtered at $1 \mathrm{kHz}$ and stored on magnetic tape using a digital data recorder (Instrutech, Gt Neck, NY, USA) while being simultaneously digitized using pClamp 6.1 (Axon Instruments, Foster City, CA, USA; sampling rate of $2 \mathrm{kHz}$ ). In many cases, voltage protocols were repeated two or three times and the resultant currents averaged. Corrections were not made for liquid junction potentials. During recording of membrane currents evoked by step depolarizations, leak and capacitance currents were subtracted using the $\mathrm{P} / 4$ method with hyperpolarizing pulses from the holding potential.

\section{Fura-2 fluotimetry}

Single ASM cells were studied using a Deltascan system (Photon Tech. Int., Sth Brunswick, NJ, USA). After settling onto a glass coverslip mounted on a Nikon inverted microscope (Diaphot, Garden City, NY, USA), cells were loaded with the membrane-permeant form of fura-2 (fura- $2 / \mathrm{AM} ; 2 \mu \mathrm{M}$ ) at $37^{\circ} \mathrm{C}$ for $30 \mathrm{~min}$, then superfused continuously with Ringer's buffer $2-3 \mathrm{~mL} \cdot \mathrm{min}^{-1}$. Only cells which exhibited reversible contractions to acetylcholine were used. Light from a $75 \mathrm{~W}$ xenon lamp was monochromatically filtered to restrict excitation light to 340 or 380 $\mathrm{nm}$ wavelengths (10 nm bandwidth). Cells were illuminated alternately at excitation wavelengths of 340 and 380 $\mathrm{nm}$ and the emitted fluorescence (measured at $510 \mathrm{~nm}$ ) induced by $340 \mathrm{~nm}$ excitation (F340) and that induced by 380 $\mathrm{nm}$ excitation (F380) was measured using a photomultiplier tube assembly. $F 340 / F 380$ were converted to $\left[\mathrm{Ca}^{2+}\right]$ as described previously [19]; the dissociation constant (KD) was assumed to be $226 \mathrm{nM}$, and the fluorescence ratio of $\mathrm{Ca}^{2+}$-free fura-2 $(R \min )$, the fluorescence ratio of $\mathrm{Ca}^{2+}$-saturated fura-2 $(R \max )$, and ratio of fluorescence measured at $380 \mathrm{~nm}$ of $\left(\mathrm{Ca}^{2+}\right.$-free fura- 2$) /\left(\mathrm{Ca}^{2+}\right.$-bound fura- 2$)(\mathrm{S} f 380 /$ Sb380) were determined previously to be $0.45,4.0$ and 15.4 , respectively. Control responses to cholinergic stimulation (i.e. peak elevation of $\left[\mathrm{Ca}^{2+}\right]$ ) were obtained, then cells were exposed to cromolyn, nedocromil or vehicle for 5-10 min before obtaining a second cholinergic response.

\section{Muscle baths}

Tracheal strips were fastened at one end to a Grass FT.03 force transducer using silk thread (Ethicon 4-0 Johnson \& Johnson, Markham, Canada) and the other end was anchored. Electrical stimulation was supplied via the platinum hook that served as the anchor and another platinum pole not in direct contact with the tissue (the two poles were $2 \mathrm{~cm}$ apart). Tissues were bathed in KrebsRinger's buffer (see below for composition) containing indomethacin $(10 \mu \mathrm{M})$, bubbled with $95 \% \mathrm{O}_{2} / 5 \% \mathrm{CO}_{2}$ and maintained at $37^{\circ} \mathrm{C}$; preload tension was $\sim 1.25 \mathrm{~g}$ (determined previously to allow maximal responses). Tissues were equilibrated for $2 \mathrm{~h}$, during which tissues were occasionally stimulated electrically or with $\mathrm{KCl}(60 \mathrm{mM})$; bath fluid was replaced and preload tension readjusted at 2030 min intervals. After this period, the responses to cholinergic stimulation were evaluated in the presence or absence of cromolyn or nedocromil added $\sim 15 \mathrm{~min}$ before stimulation. Tissues were stimulated with 100 pulses delivered at 1 and $10 \mathrm{~Hz}$ with $5 \mathrm{~min}$ between each of these pulse trains, after which a carbachol dose-response curve was generated $\left(10^{-7}\right.$ to $\left.10^{-4} \mathrm{M}\right)$. Tissues were dried and weighed in order to express the contractile responses as grams tension developed per mg dry weight tissue; those tissues weighing $<1 \mathrm{mg}$ were not included in the statistical analysis.

\section{Solutions and chemicals}

Single cells were dissociated in Ringer's buffer containing the following (in $\mathrm{mM}$ ): $\mathrm{NaCl}, 125 ; \mathrm{KCl}, 5 ; \mathrm{CaCl}_{2}, 1$; $\mathrm{MgCl}_{2}, 1$; HEPES, 10; EDTA, 0.25; D-glucose, 10; taurine, 10; pH 7.0; collagenase (type IV, Sigma, Oakville, Ontario, Canada; $2.6 \mathrm{U} \cdot \mathrm{mL}^{-1}$ ); elastase (type IV, Sigma; $12.5 \mathrm{U}$. $\left.\mathrm{mL}^{-1}\right)$; bovine serum albumin $\left(\mathrm{BSA} ; 1 \mathrm{mg} \cdot \mathrm{mL}^{-1}\right)$. During electrophysiological and fluorimetric studies, cells were bathed in Ringer's buffer containing (in $\mathrm{mM}$ ): $\mathrm{NaCl}, 130$; $\mathrm{KCl}, 5 ; \mathrm{CaCl}_{2}, 1 ; \mathrm{MgCl}_{2}$, I; HEPES, 20; D-glucose, 10; pH 7.4. For electrophysiological studies, the electrode (i.e. intracellular) solution contained (in $\mathrm{mM}$ ): $\mathrm{KCl}, 140 ; \mathrm{CaCl}_{2}$, $0.4 ; \mathrm{MgCl}_{2}$, 1 ; EGTA, 1 ; HEPES, 20; $\mathrm{pH}$ 7.2. To facilitate the study of $\mathrm{Ca}^{2+}$ currents, $\mathrm{K}^{+}$channels were blocked using an electrode solution containing (in $\mathrm{mM}$ ): $\mathrm{CsCl}, 130$; tetraethyl ammonium chloride, $10 ; \mathrm{MgCl}_{2}, 1$; HEPES, 20; EGTA, 5; pH 7.2. Nystatin (300 units. $\mathrm{mL}^{-1}$ ) was also added to all electrode solutions to perforate the membrane and allow electrophysiological recording.

Intact tissues were studied using Krebs-Ringer's buffer containing (in $\mathrm{mM}$ ): $\mathrm{NaCl}, 116 ; \mathrm{KCl}, 4.2 ; \mathrm{CaCl}_{2}, 2.5 ; \mathrm{Na}-$ $\mathrm{H}_{2} \mathrm{PO}_{4}, 1.6 ; \mathrm{MgSO}_{4}, 1.2 ; \mathrm{NaHCO}_{3}, 22$; D-glucose, 11; and bubbled continuously to maintain $\mathrm{pH}$ at 7.4.

Chemicals were obtained from Sigma, with the exception of fura-2 acetoxymethylester (Calbiochem, La Jolla, CA, USA) and prepared as aqueous solutions.

\section{Data analysis}

Responses are reported as means \pm SEM; $n$ refers to the number of cells tested. Statistical comparisons were made using a Student's t-test and analysis of variance (ANOVA), with p-values $<0.05$ being considered significant. 


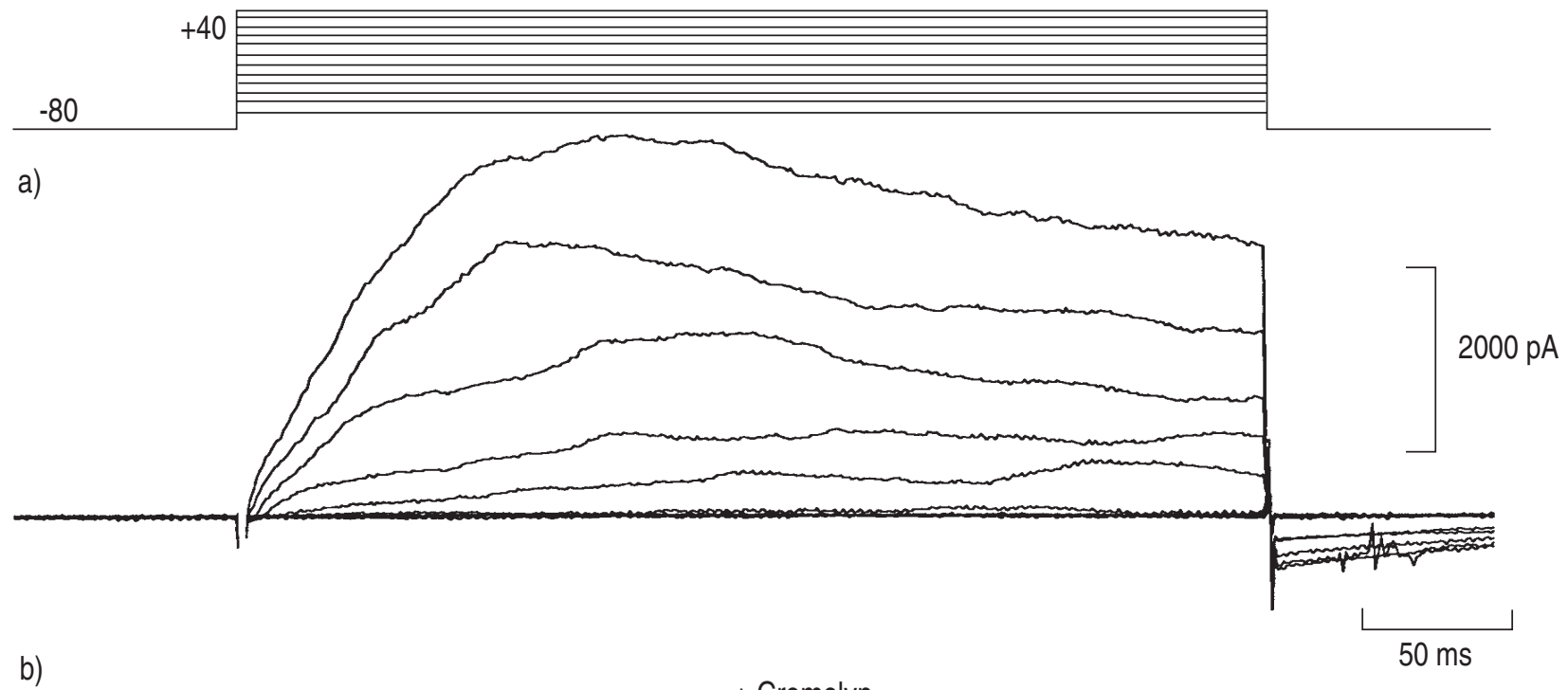

b)
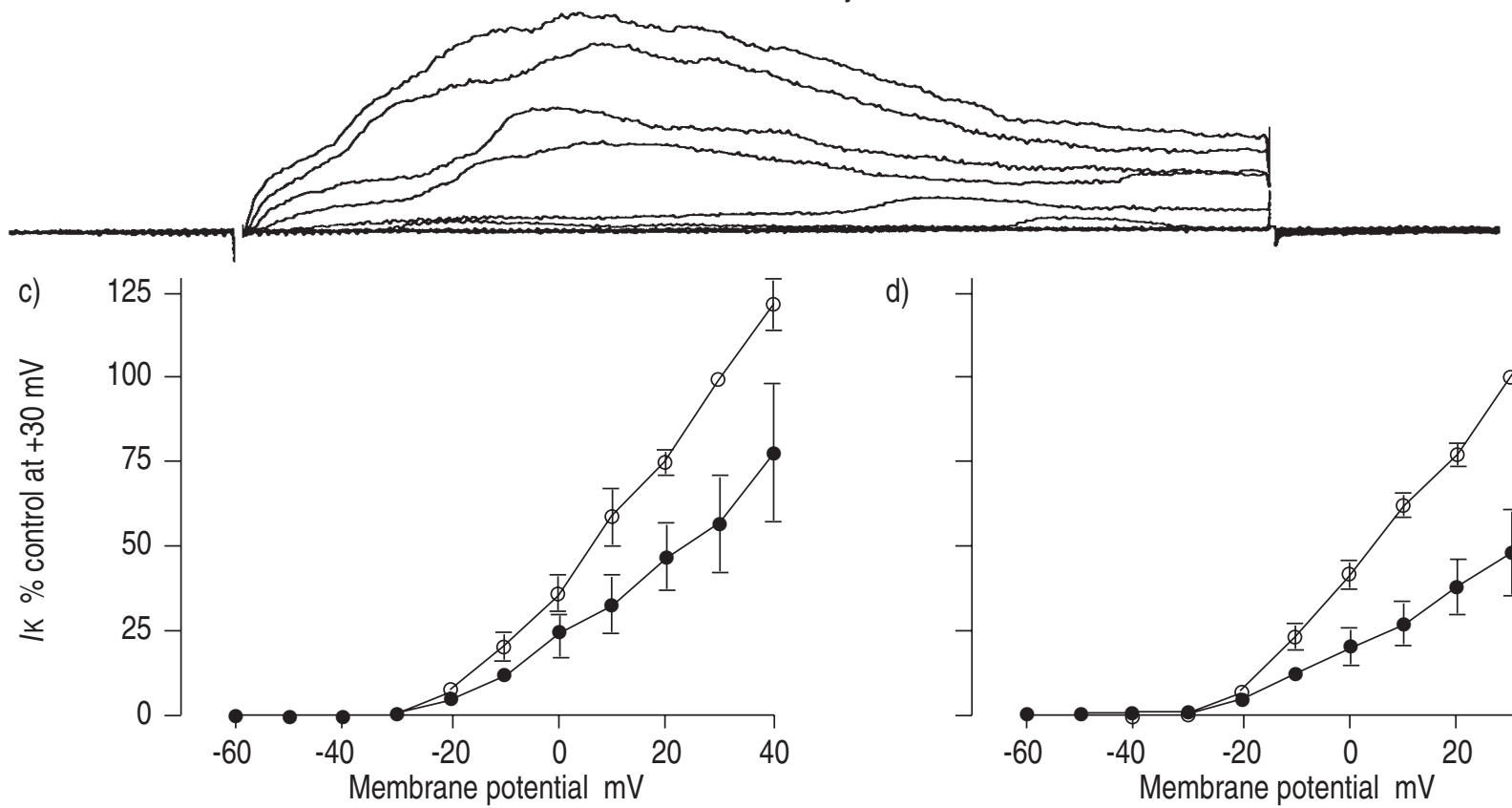

d)

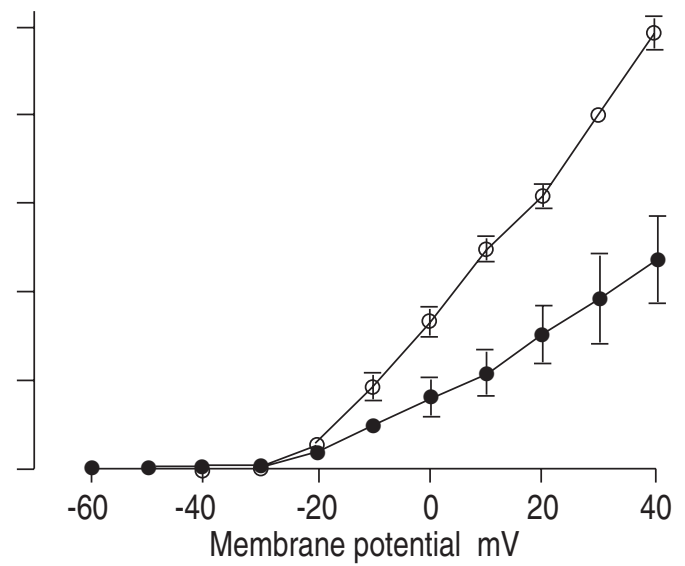

Fig. 1. - After establishing a nystatin-perforated patch preparation, canine tracheal smooth muscle was dialysed with a $\mathrm{K}^{+}$containing electrode solution. a) Depolarizing pulses ( $350 \mathrm{~ms}$ duration; $10 \mathrm{mV}$ increments) from a holding potential of $-80 \mathrm{mV}$ were used to evoke outward $\mathrm{K}^{+}$currents; in this particular cell, repolarization to the holding potential evoked inward $\mathrm{Cl}$ - tail currents. b) Application of cromolyn $\left(10^{-4} \mathrm{M}\right.$ in application pipette) markedly decreased the outward $\mathrm{K}^{+}$currents and eliminated the inward $\mathrm{Cl}$ - tail currents. Mean current-voltage relationship for peak outward $\mathrm{K}^{+}$current $(\mathrm{IK})$ in the absence (O) and presence $(\bullet)$ of c) $10^{-4}$ cromolyn $(n=7)$ or d) $10^{-4} \mathrm{M}$ nedocromil $(\mathrm{n}=6)$; currents are expressed as a percentage of the control current evoked at $+30 \mathrm{mV}$ in each cell.

Table 1. - Effect of chromones on ionic mechanisms

\begin{tabular}{|c|c|c|c|}
\hline & Cromolyn & Nedocromil & Ringer's \\
\hline $\mathrm{K}^{+}$current & $57.1 \pm 7.9 *(7)$ & $48.4 \pm 7.6^{*}(6)$ & \\
\hline & $9.1 \pm 7.3 *(7)$ & $3.2 \pm 8.2 *$ & $53.2 \pm 14.3$ \\
\hline & $31 \pm 10 *(8)$ & $111.0 \pm 20.4(6)$ & $70.1 \pm 20.0$ \\
\hline $\mathrm{Ca}^{2+}$ transient & $67.8 \pm 4.7(20)$ & $79.6 \pm 11.8$ & $78.9 \pm 13.2$ \\
\hline $\begin{array}{l}\mathrm{K}^{+} \text {and } \mathrm{Ca}^{2+} \\
\text { and }+10 \mathrm{mV} \text {, } \\
\text { were evoked } \\
\text { cells were exp } \\
\text { followed by a } \\
\text { of the initial c } \\
\text { tistical analys } \\
\text { pared with re }\end{array}$ & $\begin{array}{l}\text { cetylcholine } \\
\text { to drugs (10 } \\
\text { nd test respo } \\
1 \text { response ob } \\
{ }^{2+} \text { and } \mathrm{Cl}^{-} \mathrm{cu}\end{array}$ & $\begin{array}{l}\text { Data is expres } \\
\text { ts within the } \\
\text { ts and } \mathrm{Ca}^{2+} \text { trar }\end{array}$ & $\begin{array}{l}\text { g pulses (to }+30 \\
\text { d Ca Cat transients } \\
\text { control response, } \\
\text { or Ringer's buffer } \\
\text { sed as percentage } \\
\text { ame cell. For sta- } \\
\text { sients were com- } \\
\text { er's (*: p p }<0.05) \text {, } \\
\text { ontrol responses. } \\
\text { ticres tested }\end{array}$ \\
\hline
\end{tabular}

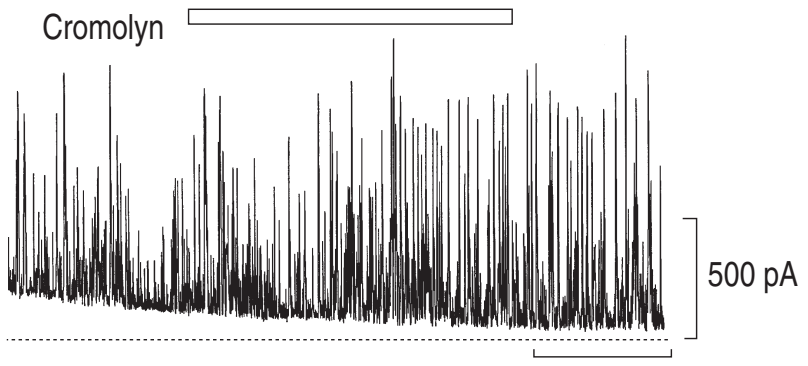

$20 \mathrm{~s}$ Fig. 2. - Spontaneous outward $\mathrm{K}^{+}$currents in a cell held continuously
at $0 \mathrm{mV}$ and dialysed with a $\mathrm{K}^{+}-$containing electrode solution. Neither the frequency nor the amplitude of these currents was altered by cromolyn $\left(10^{-4} \mathrm{M}\right.$ in application pipette; $30 \mathrm{~s}$ application). The dotted line indicates the zero current level. 


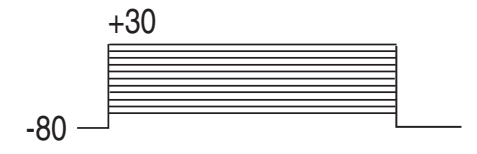

a)

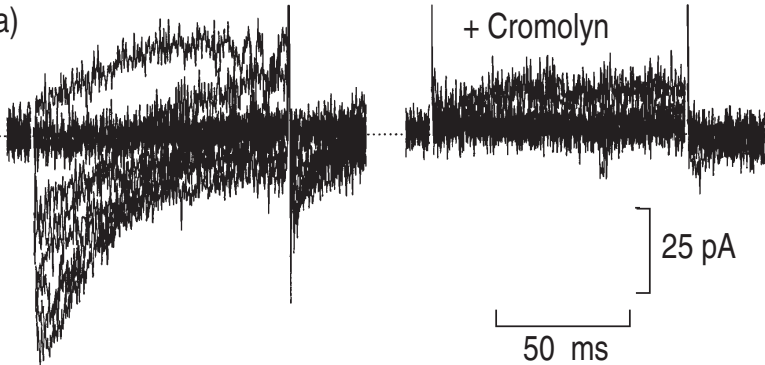

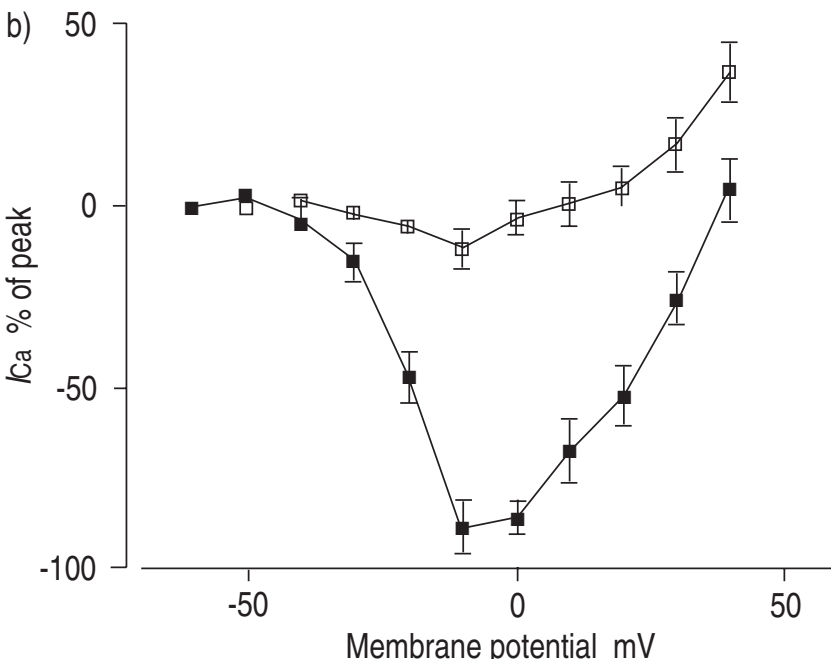

Fig. 3. - a) In a cell dialysed with a $\mathrm{Cs}^{+}-$containing solution and held at $-80 \mathrm{mV}$, depolarizing pulses (100 ms duration; $10 \mathrm{mV}$ increments) were used to evoke inward $\mathrm{Ca}^{2+}$ currents (left of figure); these were abolished by the application of cromolyn (10-4 $\mathrm{M}$ in application pipette) (right of figure). b) Mean current-voltage relationships for peak inward $\mathrm{Ca}^{2+}$ current (ICa) in the absence ( $\left.\mathbf{}\right)$ and presence $(\square)$ of $10^{-4} \mathrm{M}$ cromolyn (n=7); currents are expressed as a percentage of the largest current evoked in each cell.

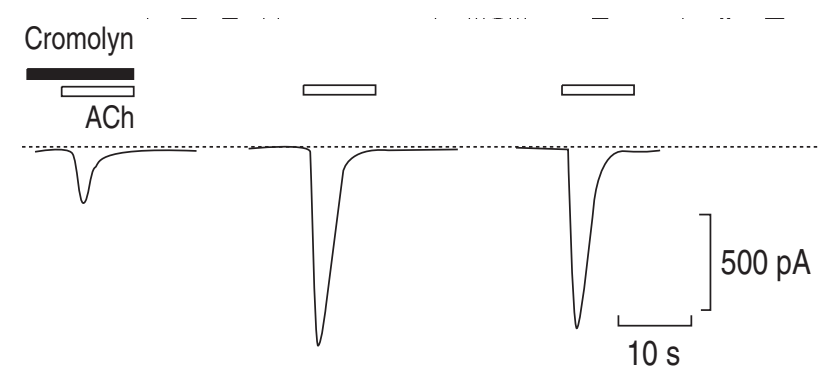

Fig. 4. - During maintained voltage clamp at $-60 \mathrm{mV}$ and in the presence of $10^{-4} \mathrm{M}$ cromolyn ( $)$, acetylcholine (ACh; $10^{-4} \mathrm{M}$ in application pipette; $\square$ ) evoked a transient inward $\mathrm{Cl}$ - current. Following wash-out of cromolyn, cholinergic responses were more than doubled in size.

\section{Results}

\section{Effects of chromones on $K^{+}$currents}

$\mathrm{K}^{+}$currents evoked by depolarizing pulses were greatly suppressed within $\sim 30 \mathrm{~s}$ after application of cromolyn (fig. $1)$. In seven cells, cromolyn reduced the $\mathrm{K}^{+}$currents recorded at $+30 \mathrm{mV}$ from $1736 \pm 287 \mathrm{pA}$ to $917 \pm 146 \mathrm{pA}$ (fig. $1 \mathrm{c}$ and table 1). Using the same experimental approach, outward $\mathrm{K}^{+}$currents were suppressed to a comparable degree by nedocromil $(1917 \pm 280 \mathrm{pA}$ versus $876 \pm 142 \mathrm{pA}$, $\mathrm{n}=6$; fig. $1 \mathrm{~d}$ and table 1 ). The study also investigated the effect on $\mathrm{K}^{+}$currents triggered by $\mathrm{Ca}^{2+}$ released spontaneously from the internal store [20]; figure 2 shows such spontaneous transient outward currents (STOC) in a cell held constantly at $0 \mathrm{mV}$. Cromolyn did not reduce either the amplitude or the frequency of the STOC, indicating that it does not antagonize $\mathrm{Ca}^{2+}$-dependent $\mathrm{K}^{+}$channels directly.

\section{Effects of chromones on voltage-dependent $\mathrm{Ca}^{2+}$ currents}

After blocking $\mathrm{K}^{+}$currents (by replacement of $\mathrm{K}^{+}$with $\mathrm{Cs}^{+}$), voltage-dependent $\mathrm{Ca}^{2+}$ currents were evoked by repeated depolarizations to $+10 \mathrm{mV}$ (100 ms duration; from the holding potential of $-80 \mathrm{mV}$ ) at $15 \mathrm{~s}$ intervals in the absence and presence of chromones $\left(10^{-4} \mathrm{M}\right.$ in application pipette). The control responses to these depolarizing pulses are given in figure $3 \mathrm{a}$, while the mean current-voltage relationship is given in figure $3 \mathrm{~b}$. Cromolyn did not alter the holding current, but greatly reduced the $\mathrm{Ca}^{2+}$ currents (fig. $3 b$ ). In seven cells studied, cromolyn reduced the peak calcium current from $46.2 \pm 7.6 \mathrm{pA}$ to $5.9 \pm 3.8 \mathrm{pA}$ (fig. $3 \mathrm{~b}$ and table 1). Likewise, nedocromil did not alter the holding current but suppressed the peak calcium current from a mean value of $40.8 \pm 15.9 \mathrm{pA}$ to $3.0 \pm 2.9 \mathrm{pA}$ (table 1 ; $\mathrm{n}=3$ ). $\mathrm{Ca}^{2+}$ currents were also reduced, though to a much lesser extent, during application of vehicle alone (Ringer's) (table 1), possibly due to run-down [21].

\section{Effects of chromones on agonist-evoked $\mathrm{Cl}$-current and Ca ${ }^{2+}$-release}

Figure 4 shows the membrane current evoked by acetylcholine (ACh) $\left(10^{-4} \mathrm{M}\right)$ in a single canine tracheal ASM cell: this current was considerably smaller in the presence of cromolyn than in its absence (fig. 4). In eight cells studied in the same way, the ACh-evoked current was $161 \pm 38$ $\mathrm{pA}$ and $958 \pm 120 \mathrm{pA}$ in the presence and absence of cromolyn, respectively (table 1). While cromolyn seemed to also moderately reduce $\mathrm{ACh}$-evoked $\mathrm{Ca}^{2+}$-release (fig. 5), this reduction was not significantly different from the run-down seen after cells were exposed to vehicle (table 1; responses expressed as a fraction of the control response evoked prior to exposure to cromolyn or vehicle). The absolute magnitudes of the cholinergic $\mathrm{Ca}^{2+}$ transients were $552 \pm 72 \mathrm{nM}(\mathrm{n}=20)$ in the presence of cromolyn and $318 \pm$ $44 \mathrm{nM}(\mathrm{n}=15)$ during application of vehicle alone.

Nedocromil had no significant effect on ACh-evoked membrane currents (these were $1165 \pm 577 \mathrm{pA}$ and $1398 \pm$ $247 \mathrm{pA}$ in the absence and presence of nedocromil, respectively; table 1). Similarly, there was not a significant difference between ACh-evoked $\mathrm{Ca}^{2+}$ transients in nedocromil-treated and vehicle-treated cells when these were expressed in absolute terms $(311 \pm 76 \mathrm{nM}(\mathrm{n}=12)$ and $318 \pm$ 
a)

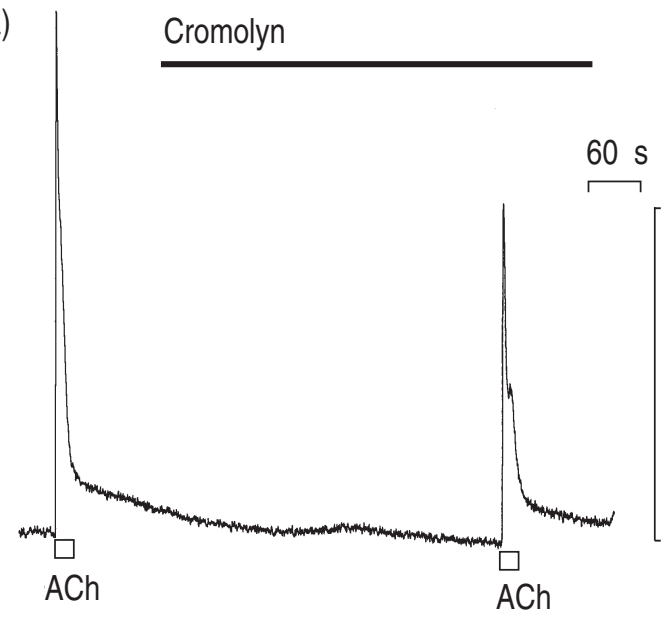

b)

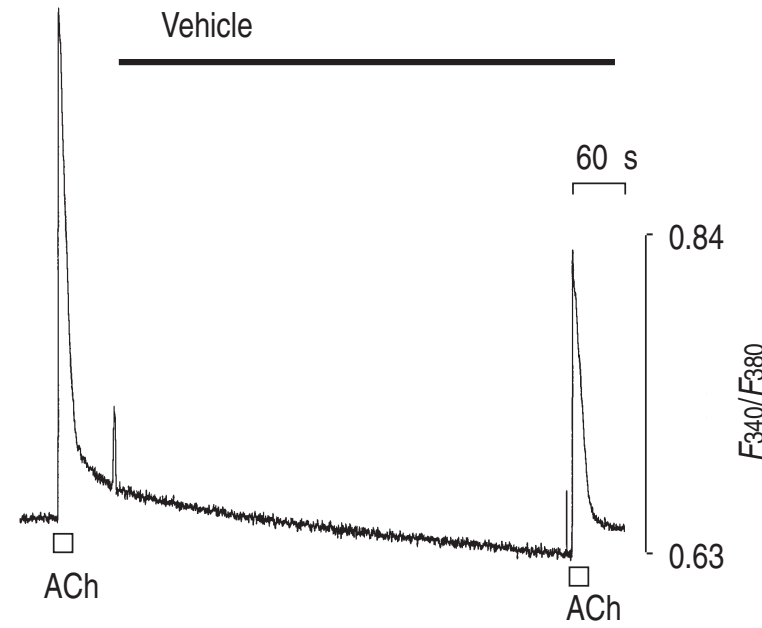

Fig. 5. - In canine tracheal myocytes loaded with fura-2, acetylcholine ( $\mathrm{ACh} ; 10^{4} \mathrm{M}$ in application pipette; $\square$ ) evoked transient elevations in the emitted fluorescence induced by $340 \mathrm{~nm}$ and that induced by $380 \mathrm{~nm}$ excitation $\left(F_{340} / F_{380}\right)$, indicating an elevation in [Ca $\left.{ }^{2+}\right]$. The cells were then exposed to a) cromolyn $\left(10^{4} \mathrm{M}\right)$ or b) vehicle (Ringer's). A second application of acetylcholine evoked another $\mathrm{Ca}^{2+}$ transient which was $\sim 60 \%$ of the control response in both cases.
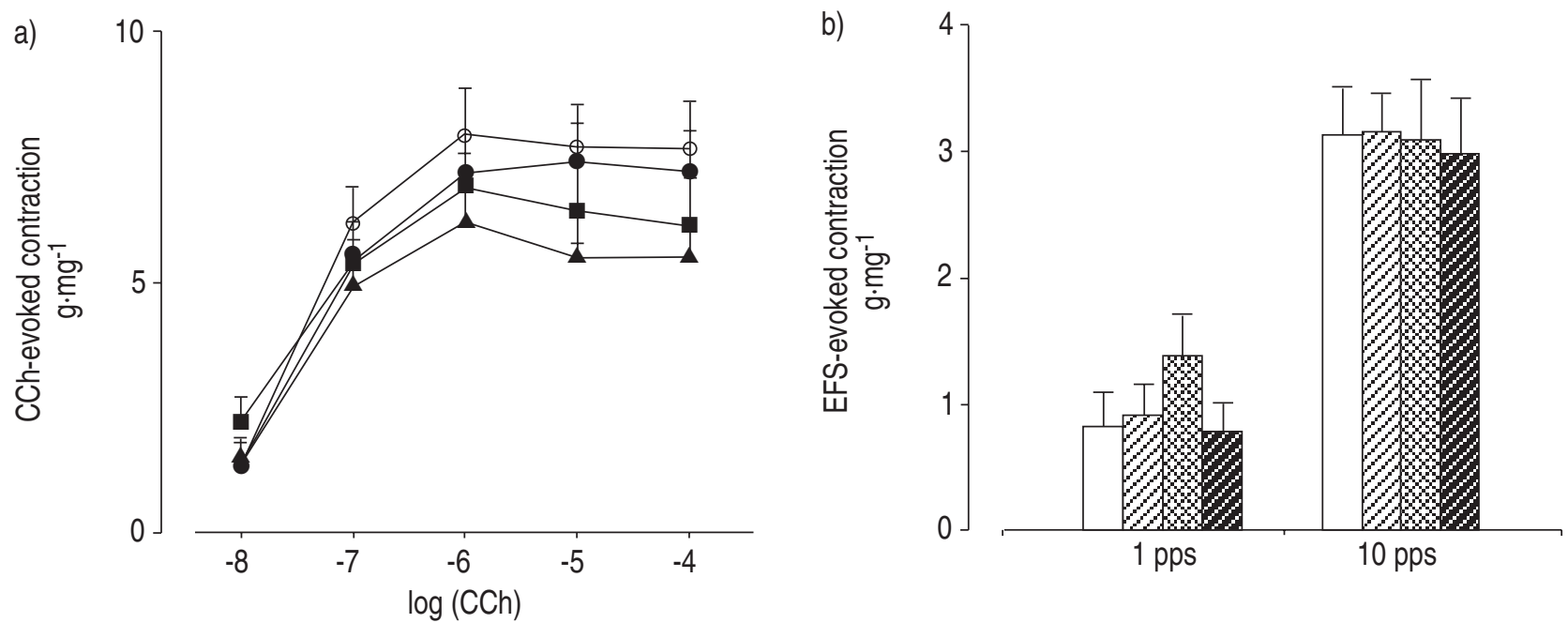

Fig. 6. - a) Mean carbachol (CCh) dose-response curves and b) responses to electrical field stimulation (EFS; 100 pulses at 1 or 10 pulses per second (pps), as indicated) were examined in strips of trachealis muscle in the absence or presence of cromolyn. a) $\bigcirc$ : control; $\bullet: 10^{-6} \mathbf{M} ; \mathbf{m}: 10^{-5} \mathbf{M} ; \mathbf{\Lambda}: 10^{-4} \mathbf{M}$.

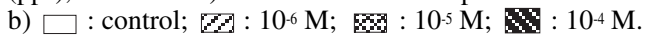

$44 \mathrm{nM}(\mathrm{n}=11)$ respectively) or as a fraction of a control response in the same cells (table 1).

\section{Effects of chromones on agonist-evoked contractions}

Cumulative dose-response curves for carbachol were generated in the absence or presence of cromolyn or nedocromil (final bath concentrations of $10^{-6}, 10^{-5}$, and $10^{-4} \mathrm{M}$ ). Neither chromone induced a change in basal tension. While the maximal response to carbachol was significantly smaller in the presence of $10^{-5}$ and $10^{-4} \mathrm{M}$ cromolyn compared with control (fig. 6a; table 2), there was no accompanying change in the carbachol medium effective concentration (EC50) values (table 2); the contractile responses to electrical stimulation were also unaffected by cromolyn (fig. 6b). Nedocromil had no significant effect on the responses to either exogenously added carbachol (neither EC50 nor maximum) or nerve-released ACh (fig. 7 and table 2).
Table 2. - Effect of chromones on acetylcholine contractions

\begin{tabular}{lll}
\hline & & $\log$ EC50 \\
\hline Cromolyn & Control & $-7.48 \pm 0.06$ \\
& $10^{-6} \mathrm{M}$ & $-7.40 \pm 0.02$ \\
& $10^{-5} \mathrm{M}$ & $-7.50 \pm 0.09$ \\
\multirow{3}{*}{ Nedocromil } & $10^{-4} \mathrm{M}$ & $-7.49 \pm 0.07$ \\
& Control & $-7.31 \pm 0.04$ \\
& $10^{-6} \mathrm{M}$ & $-7.75 \pm 0.14$ \\
& $10^{-5} \mathrm{M}$ & $-7.60 \pm 0.08$ \\
& $10^{-4} \mathrm{M}$ & $-7.52 \pm 0.12$
\end{tabular}

Cumulative carbachol concentration-response curves were generated in the presence of varying concentrations of cromolyn or nedocromil (as indicated), from which half-maximally effective concentrations were derived. There was no statistically significant effect on median effective concentration (EC50) values (in each case, $\mathrm{n}$ ranged from 10-15 tissues from five dogs). 

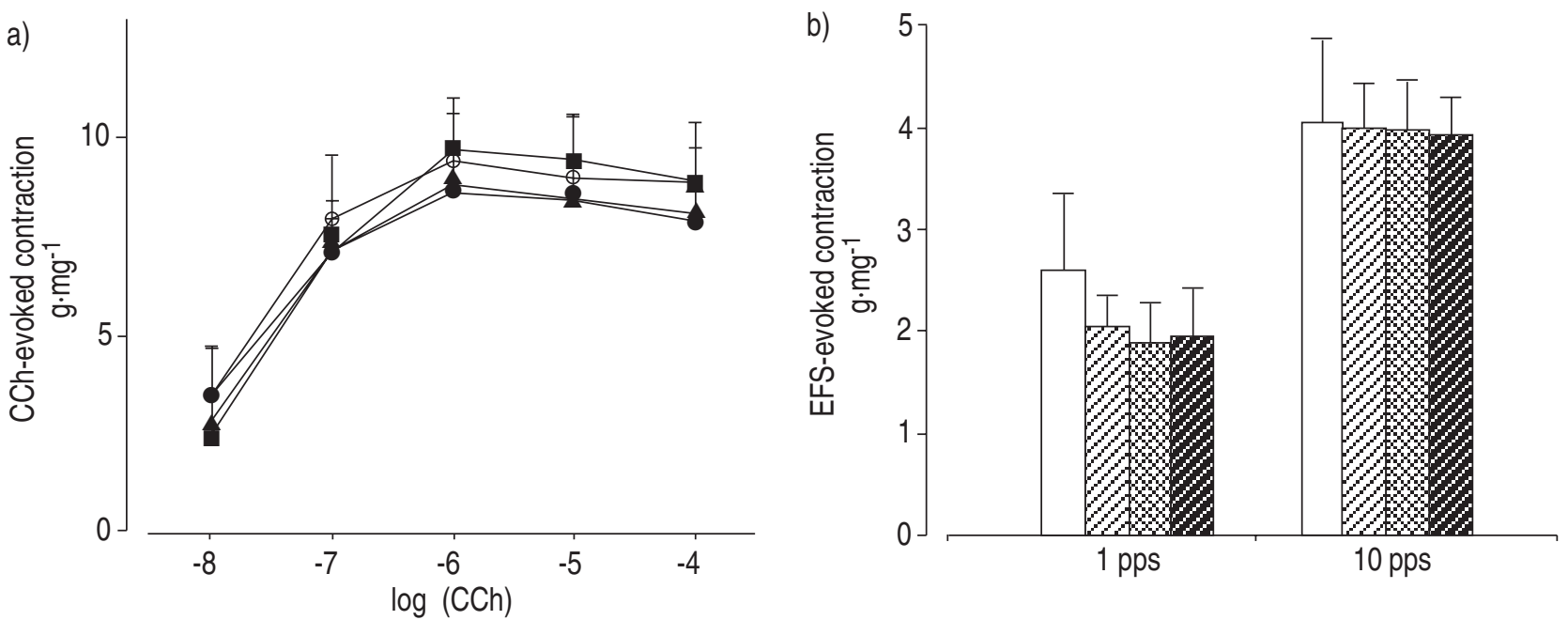

Fig. 7. - a) Mean carbachol (CCh) dose-response curves and b) responses to electrical field stimulation (EFS) in trachealis muscle in the absence or

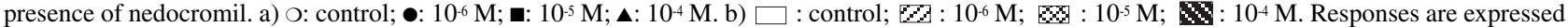
as grams tension per mg dry weight tissue. Mean responses obtained from 10-15 tissues (five animals). pps: pulses per second.

\section{Discussion}

In this study, the aim was to investigate the effects of the anti-inflammatory agents cromolyn sodium and nedocromil on ion currents and responses evoked by cholinergic stimulation. Depolarizing pulses in single myocytes dissociated from airway smooth muscle evoke a series of ion conductance changes (exemplified in fig. 1a) which include an initial small inward voltage-dependent $\mathrm{Ca}^{2+}$ current [1-4] followed by large outward delayed rectifier and $\mathrm{Ca}^{2+}-$ dependent $\mathrm{K}^{+}$currents $[1,4]$, as well as a $\mathrm{Ca}^{2+-}$ dependent $\mathrm{Cl}$ - current [5]. Upon repolarization to the holding potential, some cells (including the one in fig. 1a) exhibit large $\mathrm{Cl}$ - tail currents with time constants of hundreds of milliseconds [5].

\section{Voltage-dependent $\mathrm{Ca}^{2+}$ channels}

Cromolyn and nedocromil antagonized voltage-dependent $\mathrm{Ca}^{2+}$ currents in canine tracheal myocytes. The observation that vehicle alone did not mediate the same suppression of $\mathrm{Ca}^{2+}$ current indicates that a nonspecific effect (e.g. puffer pressure or trace amounts of metals in the applied solution) is not responsible for the chromone-induced suppression. These agents also suppress a $\mathrm{Ca}^{2+}$ conductance in mast cells, although this pathway is voltage independent and activated by depletion of the internal $\mathrm{Ca}^{2+}$ pool [13]. It is not surprising that these agents are capable of influencing voltage-dependent $\mathrm{Ca}^{2+}$ channel activity, given that their chemical structure, i.e. a series of aromatic rings with highly polar molecular groups, is similar to that of a number of other classes of $\mathrm{Ca}^{2+}$ channel blockers, including dihydropyridines (e.g. nifedipine), piperidines, benzothiazepines and phenylalkylamines [21]. Although able to abolish voltage-dependent $\mathrm{Ca}^{2+}$ currents, cromolyn and nedocromil were relatively ineffective against contractile responses to cholinergic stimulation (which are largely pharmacomechanically mediated); in like fashion, classical blockers of voltage-dependent $\mathrm{Ca}^{2+}$ channels are generally not useful in reversing cholinergically induced bronchoconstriction.

\section{$K^{+}$currents}

Cromolyn and nedocromil also suppressed depolarization-evoked $\mathrm{K}^{+}$currents in these cells. This was clearly not a direct effect on $\mathrm{Ca}^{2+}$-dependent $\mathrm{K}^{+}$currents, since spontaneous $\mathrm{K}^{+}$currents (which are triggered by $\mathrm{Ca}^{2+}$ re-leased from the sarcoplasmic reticulum) were unaffected. However, $\mathrm{Ca}^{2+}$-dependent $\mathrm{K}^{+}$currents are also triggered by voltage-dependent $\mathrm{Ca}^{2+}$ influx, and the latter were found to be nearly abolished by the chromones. Previous studies using canine tracheal ASM have shown that any method which abolishes $\mathrm{Ca}^{2+}$ currents also suppresses the depolarization-evoked $\mathrm{Ca}^{2+}$-dependent $\mathrm{K}^{+}$current in exactly the same manner as shown in this study during application of chromones $[4,22]$. It is unlikely that the delayed rectifier $\mathrm{K}^{+}$current was suppressed greatly by the chromones. Otherwise, the abolition of the voltage-dependent $\mathrm{Ca}^{2+}$ current and $\mathrm{Ca}^{2+}$-dependent $\mathrm{K}^{+}$current, together with a suppression of delayed rectifier $\mathrm{K}^{+}$current, would result in nearly complete reduction of all depolarization-evoked current: contrary to this prediction, a sizeable fraction of $\mathrm{K}^{+}$current remained in the presence of the chromones. Thus, the partial reduction of $\mathrm{K}^{+}$current by chromones was interpreted as reflecting decreased $\mathrm{Ca}^{2+}$-dependent $\mathrm{K}^{+}$current secondary to inhibition of voltage-dependent $\mathrm{Ca}^{2+}$ current. Suppression of $\mathrm{K}^{+}$currents is one pathway by which spasmogens depolarize a cell and mediate their mechanical effects $[5,8,9]$; however, chromones do not evoke such an electromechanically mediated contraction, since voltagedependent $\mathrm{Ca}^{2+}$ channels are also blocked.

\section{Cl- currents}

Protocols have previously been developed whereby $\mathrm{Ca}^{2+}$ dependent $\mathrm{Cl}^{-}$currents are elicited by depolarizationevoked $\mathrm{Ca}^{2+}$ influx [5] or by, agonist-evoked release of internally sequestered $\mathrm{Ca}^{2+}[8,9]$. While the former protocol might have been useful in investigating the effects of the anti-inflammatory agents on $\mathrm{Cl}$ - currents, the finding that voltage-dependent $\mathrm{Ca}^{2+}$ influx is abolished by the clinical agents precludes this approach. Therefore, the effects 
of these agents on acetylcholine-evoked $\mathrm{Ca}^{2+}$ release and $\mathrm{Cl}$ - currents were investigated and it was found that the latter were also reduced by cromolyn. Others have shown cromolyn to suppress intermediate conductance, $\mathrm{Ca}^{2+-i n-}$ dependent $\mathrm{Cl}^{-}$channels on mast cells and colonic carcinoma cells [14], a small conductance, volume-activated $\mathrm{Cl}^{-}$current on endothelial cells [17], a $\mathrm{Ca}^{2+}$ independent $\mathrm{Cl}^{-}$channel on mouse 3T3 fibroblasts [16] and a voltage -dependent, $\mathrm{Ca}^{2+-}$ dependent $\mathrm{Cl}$ - channel on airway epithelial cells [15]. The $\mathrm{Cl}^{-}$channels in canine airway smooth muscle are of a small-conductance, $\mathrm{Ca}^{2+}$-dependent variety $[5,20]$; the agonist-evoked current remaining in the presence of cromolyn may represent the nonselective cation current described previously $[8,9]$. Cromolyn seemed to be acting directly on the $\mathrm{Cl}$ - channels, since ACh-evoked $\mathrm{Ca}^{2+}$ transients (which trigger the $\mathrm{Cl}^{-}$currents) were not significantly affected. The chemical structure of cromolyn (a large carboxylic acid with a number of aromatic rings) is similar to that of many other $\mathrm{Cl}^{-}$channel blockers, including niflumic acid and 4-acetimido-4'-isothiocyanatostilbene-2,2'disulphonic acid (SITS). Curiously, nedocromil had relatively little effect against ACh-evoked Cl-currents in this study of canine airway smooth muscle, even though it has many structural similarities with cromolyn, niflumic acid and SITS. One important difference between them, however, is that the three aromatic rings in nedocromil are not free to rotate relative to one another, while those of cromolyn, niflumic acid and SITS are free to do so around the alkyl chain or amine group which joins them. In contrast to the present findings made in ASM, others found nedocromil to be more potent than cromolyn with respect to blocking $\mathrm{Cl}^{-}$channels in mouse 3T3 fibroblasts [16]. This tissue-related difference may reflect a channel subtype specificity of the chromones $\left(\mathrm{Ca}^{2+-}\right.$ dependent versus $\mathrm{Ca}^{2+}$ independent, respectively) and/or differing mechanisms of actions of these drugs (cromolyn decreases the unitary conductance of $\mathrm{Cl}^{-}$channels in airway epithelial cells, while nedocromil decreases the open probability without any change in unitary conductance [15].

\section{Conclusions}

Cromolyn and nedocromil markedly antagonized voltagedependent $\mathrm{Ca}^{2+}$ currents in canine airway smooth muscle. While neither agent significantly altered the acetylcholine-triggered release of internal $\mathrm{Ca}^{2+}$, high concentrations of cromolyn seemed to also partially suppress acetylcholine-evoked $\mathrm{Cl}^{-}$currents and contractions. Although it might be argued that the concentrations required in this study to achieve statistical significance greatly exceed conventional therapeutic plasma concentrations, it should be pointed out that cromolyn and nedocromil are delivered by inhalation; thus, the concentrations attained in the tissues lining the airways (including the smooth muscle layer) would be likely to reach much higher levels than those found in the plasma.

\section{References}

1. Hisada T, Kurachi Y, Sugimoto T. Properties of membrane currents in isolated smooth muscle cells from guineapig trachea. Pflügers Archiv 1990; 416: 151-161.

2. Janssen LJ. T-type and L-type $\mathrm{Ca}^{2+}$ currents in canine bronchial smooth muscle: characterization and physiological roles. Am J Physiol 1997; 272: C1757-C1765.

3. Kotlikoff MI. Calcium currents in isolated canine airway smooth muscle cells. Am J Physiol 1988; 254: C793C801.

4. Muraki K, Imaizumi Y, Kojima T, Kawai T, Watanabe M. Effects of tetraethylammonium, and 4-aminopyridine on outward currents and excitability in canine tracheal smooth muscle cells. Br J Pharmacol 1990; 100: 507-515.

5. Janssen LJ, Sims SM. $\mathrm{Ca}^{2+-d e p e n d e n t ~} \mathrm{Cl}^{-}$current in canine tracheal smooth muscle cells. Am J Physiol 1995; 269: C163-C169.

6. Janssen LJ, Sims SM. Emptying and refilling of $\mathrm{Ca}^{2+}$ store in tracheal myocytes as indicated by ACh-evoked currents and contraction. Am J Physiol 1993; 265: C877C886.

7. Janssen LJ. Acetylcholine and caffeine activate $\mathrm{Cl}^{-}$and suppress $\mathrm{K}^{+}$conductances in human bronchial smooth muscle. Am J Physiol 1996; 270: L772-L781.

8. Janssen LJ, Sims SM. ACh activates non-selective cation and chloride conductances in canine and guinea-pig tracheal myocytes. J Physiol 1992; 453: 197-218.

9. Janssen LJ, Sims SM. Histamine activates $\mathrm{Cl}^{-}$and $\mathrm{K}^{+}$currents in guinea-pig tracheal myocytes: convergence with muscarinic signalling pathway. $J$ Physiol 1993; 465: 661677.

10. Barnes PJ. Anti-inflammatory therapy for asthma. Ann Rev Med 1993; 44: 229-242

11. Kaliner MA. Evolution of asthma treatments. Ann Allergy 1993; 71: 300-305.

12. Edwards AM, Stevens MT. The clinical efficacy of inhaled nedocromil sodium (Tilade $®$ ) in the treatment of asthma. Eur Respir J 1993; 6: 35-51.

13. Franzius D, Hoth M, Penner R. Non-specific effects of calcium entry antagonists in mast cells. Pflügers Archives 1994; 428: 433-438.

14. Reinsprecht M, Pecht I, Schindler H, Romanin C. Potent block of $\mathrm{Cl}$ channels by antiallergic drugs. Biochem Biophys Res Commun 1992; 188: 957-963.

15. Alton EWFW, Kingsleigh-Smith DJ, Munkonge FM, et al. Asthma prophylaxis agents alter the function of an airway epithelial chloride channel. Am J Respir Cell Mol Biol 1996; 14: 380-387.

16. Paulmichl M, Norris AA, Rainey DK. Role of chloride channel modulation in the mechanism of action of nedocromil sodium. Int Arch Allergy Immunol 1995; 107 : 416-421.

17. Heinke S, Szücs G, Norris A, Droogmans G, Nilius B. Inhibition of volume-activated chloride currents in endothelial cells by chromones. Br J Pharmacol 1995; 115: 1393-1398.

18. Jackson DM, Pollard CE, Roberts SM. The effect of nedocromil sodium on the isolated rabbit vagus nerve. Eur J Pharmacol 1992; 221: 175-177.

19. Grynkiewicz G, Poenie M, Tsien RY. A new generation of $\mathrm{Ca}^{2+}$ indicators with greatly improved fluorescence properties. J Biol Chem 1985; 260: 3440-3450.

20. Janssen LJ, Sims SM. Spontaneous transient inward currents and rhythmicity in canine and guinea-pig tracheal smooth muscle cells. Pflügers Archiv 1994; 427: 473-480.

21. McDonald TF, Pelzer S, Trautwein W, Pelzer DJ. Regulation and modulation of calcium currents in cardiac, skeletal, and smooth muscle cells. Physiol Rev 1994; 74: 365-507.

22. Kotlikoff MI. Potassium currents in canine airway smooth muscle. Am J Physiol 1990; 259: L384-L395. 